\title{
Education, conflict and development: A case study of mobile schools for pastoralists in Jammu and Kashmir
}

\author{
Kavita Suri \\ Associate Professor, Department of Lifelong Learning (Formerly, Centre for Adult, Continuing Education \& \\ Extension), University of Jатти, Јатти and Kashmir
}

\begin{abstract}
The education of pastoral communities has assumed much importance in the past few years keeping in view the fact that in the changing world orders and globalization, the acquisition of literacy and numeracy has become a felt need among the nomads. In Jammu and Kashmir, one of the border states of India, Gujjars and Bakkarwals are among the 12 tribes which have been accorded Schedule Tribe status. The Gujjars and Bakkarwal tribes are also the two tribes which form the third largest community in Jammu and Kashmir and constitute 8.1 percent of the total population in the state.

Primarily nomadic communities, they move to the lower, middle and higher mountain ranges of Pir Panjal mountains in the summer with their cattle and come back to the plains in the winters. The literacy rate among these tribes is quite low and they are considered as educationally backward communities. The armed conflict in Jammu and Kashmir which has entered its 25 year has also impacted the education of the Gujjars and Bakkarwals and they have greatly been disadvantaged in educational matters. Efforts to educate them including the opening of Mobile Primary Schools (MPS) by the Jammu and Kashmir government have failed to register remarkable progress. Despite various interventions to expand access to education since independence, the nomadic pastoralist communities in $J \& K$ have largely been excluded from the meaningful educational processes.
\end{abstract}

The present paper aims to study the impact of Mobile Primary Schools opened by the Jammu and Kashmir government for this nomadic population. It also aims to study the reasons for lack of access of basic education to these nomads while identifying major constraints that limit the provision of education to Gujjars and Bakkarwals. It would also recommend suitable strategies through which education could be provided to pastoral nomads which can help them lead better lives.

Keywords: Jammu and Kashmir, Nomadic tribes, Gujjars, Bakkarwals, Mobile schools

\section{Introduction}

Education is a major instrument for change and social development which plays an important role in empowering the child economically and socially and assists the marginalized population out of poverty. Education also provides the children with the means to participate fully in their communities (UNESCO, 2000). Accelerated progress in education is critical for the economic development of any nation and the achievement of the wider Millennium Development Goals (MDGs) in areas such as poverty reduction, nutrition, child survival and maternal health (Psacharopoulos and Woodhall, 1985; Lucas, 1988; Barro, 1991; Mankiw, Romer and Weil, 1992). According to the United Nations Children Fund (UNICEF), education is a fundamental human right and a key factor in reducing poverty and child labour as well as promoting sustainable development.

The world recognized the importance and improvement in access to all in education systems through various international frameworks that can be traced back to 1948 when the Universal Declaration of Human Rights was adopted. In this bill of rights, article 26 has a provision for a right to education for all. The World Conference on Education for All (EFA) held in Jomtien, Thailand in 1990 sparked off a new impetus towards basic education especially with its vision and renewed commitment in making it available for all (Sifuna, 2005). The global commitment to EFA was reaffirmed in Dakar Senegal in April and September 2000 after a decade of slow progress. The latter meeting was a UN Millennium Summit which saw the adoption of two EFA goals that are part of the general MDGs. During this meeting only the overall MDGs were adopted by 189 nations and signed by 147 heads of state and governments (UNESCO, 2000).

With the objective to provide education to the children and prepare them as the future citizens who will be able to contribute to the process of development of their societies and families and help them live a normal life, hundreds and thousands of schools all over the world are providing educational opportunities to the children. Yet, the rough estimates suggest that over 100 million children including about 60 million girls have no access to primary education. There is also a huge population of nomadic communities all over the world mainly in Africa, the Middle East, South-West, Central Asia and South Asia who have alarmingly low literacy rates. 
In 1990, Article 3 of the World Declaration on Education for All (EFA) identified nomads as one of several groups who are discriminated against in access to education services and demanded 'an active commitment' to removing educational disparities. Twenty years on, the 2010 Education for All Global Monitoring Report, 'Reaching the Marginalised', noted that this challenge had become urgent: in the rapid progress towards Education for All (EFA), pastoralists have been left far behind (GMR 2010, 179) and continue to face extreme educational disadvantage. Millions of nomadic children are outside the education system and have low school enrolment, attendance, classroom performance, achievement, continuity to higher education and gender balance.

Though there is no overall figure available for South Asia but the significant concentrations of pastoralists are in Pakistan and across India, in both the Himalayan region and semi-arid zones. In South Asia, like elsewhere in the world, nomads are among the most marginalized social groups who are widely excluded from educational provision, despite pledges of Education for All. The practice of pastoralism, i.e., the phenomenon of migration itself presents many challenges in achieving education for all.

\section{Education for Nomads}

The education of pastoralist communities has assumed much importance in the past few years keeping in view the fact that in the changing world orders and globalization, the acquisition of basic functional literacy and numeracy is a felt need among the nomads who need to comprehend those things which affect their occupational roles like useful direction tax, understand instructions on health and animals treatment and schemes relating to animal husbandry etc. They also need to read and understand various polices introduced by the respective state and central governments for their betterment and avail the same. In recent years, problems such as overgrazing of limited resources, punitive local taxes etc. have thrown up more and more challenges to pastoralists which they have sought to meet by various adaptation strategies (Choksi \& Dyer, 1996) including education, Small little things like writing, reading, written communications with veterinary, agriculture and livestock officers on how to improve their herds etc., small simple calculations and keeping record relating to the numbering their herds, cost and returns from investment on improved herding and grazing, distance covered on seasonal movements etc. is very important. Besides, education can also help them in the improvement in their socio-economic status if they learn to know about better marketing of their products such as meat, milk, and butter by application of modern technology and use modern savings and bank credit facilities which can enable them integrate better with the rest of the population.

Pastoralists have increasingly become aware about the importance of education and thus no longer resist the idea of formal education in comparison to older times. Children and adults now fully understand the importance of education and are enthusiastic about learning. However, the main obstacle in the education of nomads is effective access to education. There is no adequate infrastructure for imparting quality education to them.

In India too, the demand for education among pastoralists including children is rapidly increasing. Education is seen by impoverished nomadic households as a way out of poverty and by the households actively involved in pastoral production as a way to support their production system in an increasingly globalised world. However, the education system has failed to respond to this demand.

\section{Nomads of Jammu and Kashmir}

Nomadic pastoralists are found in the arid zones of Jammu and Kashmir, Himachal Pradesh, Rajasthan, Gujarat etc. Jammu and Kashmir is one of the border states of India, has a total population of 1,25,41302 including male population of 66,40662 and female population of 59,00640. The Scheduled Tribes account for 11.9 per cent of the total population of the State as per Census 2011. In Jammu and Kashmir, there are 12 Scheduled Tribes which were enumerated officially for the first time during the 2001 census recording a population of 1,105,979. The Census 2011 shows the entire ST population of the state at 14, 93, 299 in comparison to 11,0,5979 of Census 2001. Out of twelve Scheduled Tribes, Gujjar is the most populous tribe having a population of 763,806 , thus forming 69.1 percent of the total ST population. Bot is the second major tribe having a population of 96,698 , followed by Bakkarwal $(60,724)$ and Brokpa $(51,957)$. Gujjar along with the three tribes constitute 88 per cent of the total tribal population (Census 2001)

Table 1: Population of Schedules Tribes in J\&K

\begin{tabular}{|l|l|l|l|}
\hline NAME & $\begin{array}{l}\text { POPULATION OF ST Census } \\
\mathbf{2 0 1 1}\end{array}$ & $\begin{array}{l}\text { POPULATION OF } \\
\text { Census 2001 }\end{array}$ & ST \\
\hline JAMMU \& KASHMIR & $14,93,299$ & $11,0,5979$ & $3,87,320$ \\
\hline Kupwara & 70352 & 51753 & 18599 \\
\hline Badgam & 23912 & 14547 & 9365 \\
\hline Leh & 95,857 & 96,174 & -317 \\
\hline Kargil & $1,22,336$ & $1,05,377$ & 16959 \\
\hline Punch & $1,76,101$ & $1,49,018$ & 27083 \\
\hline
\end{tabular}


Education, conflict and development: A case study of mobile schools for pastoralists in Jammu and

\begin{tabular}{|l|l|l|l|}
\hline Rajouri & $2,32,815$ & $1,60,049$ & 72766 \\
\hline Kathua & 53307 & 33969 & 19338 \\
\hline Baramulla & 37705 & 28886 & 8819 \\
\hline Bandipore & 75374 & 54996 & 20378 \\
\hline Srinagar & 8935 & 3485 & 5450 \\
\hline Ganderbal & 61070 & 41959 & 19111 \\
\hline Pulwama & 22607 & 10552 & 12055 \\
\hline Shopian & 21820 & 10944 & 10876 \\
\hline Anantnag & $1,16,006$ & 80,856 & 35150 \\
\hline Kulgam & 26525 & 20287 & 6238 \\
\hline Doda & 39216 & 28400 & 10816 \\
\hline Ramban & 39772 & 29353 & 10419 \\
\hline Kishtwar & 38149 & 27917 & 10232 \\
\hline Udhampur & 56309 & 42875 & 13434 \\
\hline Reasi & 88365 & 60753 & 27612 \\
\hline Jammu & 69193 & 42089 & 27104 \\
\hline Samba & 17573 & 11740 & 5833 \\
\hline
\end{tabular}

Source: Census 2011

The Gujjars and Bakkarwal tribes are the two nomadic tribes which form the third largest community in Jammu and Kashmir and constitute 8.1 percent of the total population in the state, according to the census of India 2001. In Jammu and Kashmir in India, Gujjars and Bakkarwals are found in all the three regions of the state including Jammu (comprising districts of Jammu, Kathua, Udhampur, Poonch, Rajouri etc), the Kashmir Valley (comprising the districts of Srinagar, Baramulla, Kupwara, Pulwama, Budgam and Anantnag) and Ladakh (comprising Kargil).

Gujjars were primarily a nomadic community who have now settled down to a large extent and have become sedentarized or settled in permanent villages in the plains bordering the foot hills and have taken to cultivation of land as their primary occupation. Besides, there are semi-settled or sedentary transhumant Gujjars who combine the cultivation of land with pastoralism. They move to the lower and middle mountain areas and Pir Panjal pastures in the summer with their flock of buffalos where they engage in cultivation and come back to the plains in the winters. Bakkarwals are primarily pastoralists rearing goat and sheep for livelihood. They leave their homes each summer for the high-altitudes of Himalayas and spend their winter in plains and foot hills of Shivaliks. During their journeys to the higher reaches of the mountains during summer when the snows melt and the passes open, the Bakkarwals trek through the remotest areas of the mountains to reach the higher pastures of the Pir Panjal range where they rest in temporary hutments in the picturesque valley and graze their herd of sheep. In those high altitude pastures which are excellent grazing grounds for their cattle, they graze their cattle, fatten their flock and achieve higher prices for their sheep. In autumn, having sold their sheep, they descend to the plains leaving the extreme cold of the mountains behind them in October. The tribe is greatly dependent on its livestock and hence the need for higher pastures and colder climates makes the community embark on a journey, sometimes stretching for weeks and months on foot.

\section{Nomads, education and conflict in Jammu and Kashmir}

The nomads of Jammu and Kashmir, especially the Gujjars and Bakkarwals have badly been hit by the armed conflict that engulfed the border state in 1989. Since the beginning of the armed insurgency in the border state, the Gujjar and Bakkarwal tribes were unwittingly drawn into this conflict. Though both the tribes have been hit by the violence, the nomadic Bakkarwals have suffered more than the Gujjars due to their annual migration across Pir Panjal mountain ranges.

In all these 25 years of protracted conflict in the state, the Gujjar Bakkarwal tribe found itself caught between the security forces and the militants. The conflict in Jammu and Kashmir has transformed the lives of Gujjars and Bakkarwals. The worsening of the security situation in Jammu in the mid-1990s did not stop the two great annual migrations of the Bakkarwals but it did expose them to new pressures. As the terrorists would remain hidden in the dense forests in the upper reaches of the mountains especially in Pir Panjal ranges, the Bakkarwals who would also go to the higher reaches were seen as a keen element in the escalated violence in Jammu and Kashmir. Travelling to far flung regions they would often come into contact with the militants who also used these areas to hide from the security forces. The security forces would see the journeys of Bakkarwals to the higher regions as a support to the various terrorist outfits operating in the higher ridges. Not only the nomads meant food for the militants but also a plethora of other support like sneaking past the security forces with the nomads posing off as part of their caravans while hiding their arms and ammunition in their belongings atop the horses that the Bakarwals possessed. The insurgents focused their main mobilization efforts on these pastoralists. The education of the nomads also suffered a lot as the mobile schools which were set up for the children of the pastoral communities were closed and converted into stationary schools. The nomadic children had no one to teach them in the wild. 
The Mobile Primary Schools (MPS) commonly known as mobile schools were set up by the J\&K government in 1970s with the objective to provide educational facilities to the children of nomadic Gujjar and Bakkarwal Scheduled Tribes (STs). The mobile schools which were single teacher primary schools providing education facilities to the children of the nomads at various places especially in upper reaches of Pir Panjal mountains, could not continue for long after the onset of armed conflict in the state.

As such the tribes were already having low literacy rates in J\&K. As per census 2001, the literacy rate of tribal population in $\mathrm{J} \& \mathrm{~K}$ is 37.5 per cent which is far lower than the average literacy 47.1 per cent of tribal at national level. The literacy rate of male of tribals of $\mathrm{J} \& \mathrm{~K}$ (48.2 percent) is much lower than the tribals at national level (59.2 per cent). Also the literacy rate of female tribals ( 25.5 per cent) of $\mathrm{J} \& \mathrm{~K}$ is low in comparison to female tribals at national level (34.8 per cent). (Andrabi 2013). The literacy rate in Jammu and Kashmir is 68.74 per cent as per Census 2011 with male literacy at 78.26 per cent and female literacy at 58.01 per cent.

Table 2: Child Population, Enrolment \& Out of School Children (For Scheduled Tribes: 6-11 age group and 11-14 age group

\begin{tabular}{|c|c|c|c|c|c|c|c|c|c|c|}
\hline \multirow[t]{3}{*}{ S.No. } & \multirow{3}{*}{$\begin{array}{l}\text { Name of Block/ } \\
\text { Municipal Area }\end{array}$} & \multicolumn{3}{|c|}{ Child Population } & \multicolumn{3}{|c|}{ Enrolment } & \multicolumn{3}{|c|}{ Out of School Children } \\
\hline & & \multicolumn{3}{|c|}{$\begin{array}{l}\text { Scheduled Tribes } \\
\text { (6-11 age group) }\end{array}$} & \multicolumn{3}{|c|}{$\begin{array}{l}\text { Scheduled Tribes } \\
\text { (6-11 age group) }\end{array}$} & \multicolumn{3}{|c|}{$\begin{array}{l}\text { Scheduled Tribes } \\
\text { (6-11 age group) }\end{array}$} \\
\hline & & B & G & $\mathbf{T}$ & B & G & $\mathbf{T}$ & B & $\mathbf{G}$ & $\mathbf{T}$ \\
\hline 1 & 2 & 3 & 4 & 5 & 6 & 7 & 8 & 9 & 10 & 11 \\
\hline 1 & ANANTNAG & 6118 & 5236 & 11354 & 6067 & 5188 & 11255 & 51 & 48 & 99 \\
\hline 2 & BADGAM & 1758 & 1618 & 3376 & 1685 & 1546 & 3231 & 73 & 72 & 145 \\
\hline 3 & BANDIPORA & 4739 & 4075 & 8814 & 4640 & 3980 & 8620 & 99 & 95 & 194 \\
\hline 4 & BARAMULA & 3316 & 2718 & 6034 & 2958 & 2472 & 5430 & 358 & 246 & 604 \\
\hline 5 & DODA & 2962 & 2408 & 5370 & 2937 & 2345 & 5282 & 25 & 63 & 88 \\
\hline 6 & GANDERBAL & 3723 & 3352 & 7075 & 3563 & 3129 & 6692 & 160 & 223 & 383 \\
\hline 7 & JAMMU & 6853 & 5570 & 12423 & 6809 & 5535 & 12344 & 44 & 35 & 79 \\
\hline 8 & KARGIL & 7289 & 7608 & 14897 & 7259 & 7564 & 14823 & 30 & 44 & 74 \\
\hline 9 & KATHUA & 3952 & 3163 & 7115 & 3823 & 2969 & 6792 & 129 & 194 & 323 \\
\hline 10 & KISHTWAR & 3052 & 2219 & 5271 & 2865 & 2077 & 4942 & 187 & 142 & 329 \\
\hline 11 & KULGAM & 1950 & 1802 & 3752 & 1851 & 1683 & 3534 & 99 & 119 & 218 \\
\hline 12 & KUPWARA & 4589 & 3848 & 8437 & 4450 & 3670 & 8120 & 139 & 178 & 317 \\
\hline 13 & LEH (LADAKH) & 4716 & 4271 & 8987 & 4709 & 4258 & 8967 & 7 & 13 & 20 \\
\hline 14 & PULWAMA & 1819 & 1605 & 3424 & 1763 & 1540 & 3303 & 56 & 65 & 121 \\
\hline 15 & PUNCH & 16124 & 15167 & 31291 & 16000 & 15022 & 31022 & 124 & 145 & 269 \\
\hline 16 & RAJAURI & 18882 & 17402 & 36284 & 18526 & 16991 & 35517 & 356 & 411 & 767 \\
\hline 17 & RAMBAN & 3156 & 2505 & 5661 & 2889 & 2254 & 5143 & 267 & 251 & 518 \\
\hline 18 & REASI & 7830 & 7149 & 14979 & 7739 & 7020 & 14759 & 91 & 129 & 220 \\
\hline 19 & SAMBA & 1444 & 1140 & 2584 & 1443 & 1138 & 2581 & 1 & 2 & 3 \\
\hline 20 & SHOPIAN & 2064 & 1910 & 3974 & 1962 & 1717 & 3679 & 102 & 193 & 295 \\
\hline 21 & SRINAGAR & 809 & 638 & 1447 & 743 & 583 & 1326 & 66 & 55 & 121 \\
\hline \multirow[t]{2}{*}{22} & UDHAMPUR & 3959 & 3511 & 7470 & 3873 & 3349 & 7222 & 86 & 162 & 248 \\
\hline & Total & 111104 & 98915 & 210019 & 108554 & 96030 & 204584 & 2550 & 2885 & 5435 \\
\hline
\end{tabular}

Child Population, Enrolment \& Out of School Children (For Scheduled Tribes :11-14(age group)

\begin{tabular}{|c|c|c|c|c|c|c|c|c|c|c|}
\hline \multirow[t]{3}{*}{ S.No. } & \multirow{3}{*}{$\begin{array}{l}\text { Name of Block/ } \\
\text { Municipal Area }\end{array}$} & \multicolumn{3}{|c|}{ Child Population } & \multicolumn{3}{|c|}{ Enrolment } & \multicolumn{3}{|c|}{ Out of School Children } \\
\hline & & \multicolumn{3}{|c|}{$\begin{array}{l}\text { Scheduled Tribes } \\
\text { (11-14 age group) }\end{array}$} & \multicolumn{3}{|c|}{$\begin{array}{l}\text { Scheduled Tribes } \\
\text { (11-14 age group) }\end{array}$} & \multicolumn{3}{|c|}{$\begin{array}{l}\text { Scheduled Tribes } \\
\text { (11-14 age group) }\end{array}$} \\
\hline & & B & $\mathbf{G}$ & $\mathbf{T}$ & B & G & $\mathbf{T}$ & $\mathbf{B}$ & $\mathbf{G}$ & $\mathbf{T}$ \\
\hline 1 & 2 & 3 & 4 & 5 & 6 & 7 & 8 & 9 & 10 & 11 \\
\hline 1 & ANANTNAG & 2866 & 2110 & 4976 & 2756 & 1964 & 4720 & 110 & 146 & 256 \\
\hline 2 & BADGAM & 800 & 621 & 1421 & 754 & 552 & 1306 & 46 & 69 & 115 \\
\hline 3 & BANDIPORA & 2074 & 1530 & 3604 & 1983 & 1424 & 3407 & 91 & 106 & 197 \\
\hline 4 & BARAMULA & 1623 & 1109 & 2732 & 1296 & 767 & 2063 & 327 & 342 & 669 \\
\hline 5 & DODA & 1635 & 1018 & 2653 & 1615 & 953 & 2568 & 20 & 65 & 85 \\
\hline
\end{tabular}


Education, conflict and development: A case study of mobile schools for pastoralists in Jammu and

\begin{tabular}{|l|l|l|l|l|l|l|l|l|l|l|}
\hline 6 & GANDERBAL & 2073 & 1303 & 3376 & 1417 & 1040 & 2457 & 656 & 263 & 919 \\
\hline 7 & JAMMU & 2924 & 2203 & 5127 & 2916 & 2198 & 5114 & 8 & 5 & 13 \\
\hline 8 & KARGIL & 3622 & 3781 & 7403 & 3589 & 3709 & 7298 & 33 & 72 & 105 \\
\hline 9 & KATHUA & 1945 & 1365 & 3310 & 1897 & 1260 & 3157 & 48 & 105 & 153 \\
\hline 10 & KISHTWAR & 1156 & 665 & 1821 & 901 & 439 & 1340 & 255 & 226 & 481 \\
\hline 11 & KULGAM & 699 & 569 & 1268 & 623 & 486 & 1109 & 76 & 83 & 159 \\
\hline 12 & KUPWARA & 1887 & 1504 & 3391 & 1751 & 1370 & 3121 & 136 & 134 & 270 \\
\hline 13 & LEH & 2552 & 2725 & 5277 & 2542 & 2711 & 5253 & 10 & 14 & 24 \\
\hline 14 & PULWAMA & 712 & 483 & 1195 & 683 & 436 & 1119 & 29 & 47 & 76 \\
\hline 15 & PUNCH & 8113 & 6590 & 14703 & 8013 & 6434 & 14447 & 100 & 156 & 256 \\
\hline 16 & RAJAURI & 9301 & 7519 & 16820 & 8862 & 6925 & 15787 & 439 & 594 & 1033 \\
\hline 17 & RAMBAN & 1619 & 953 & 2572 & 1419 & 772 & 2191 & 200 & 181 & 381 \\
\hline 18 & REASI & 3570 & 2586 & 6156 & 3509 & 2512 & 6021 & 61 & 74 & 135 \\
\hline 19 & SAMBA & 622 & 476 & 1098 & 621 & 474 & 1095 & 1 & 2 & 3 \\
\hline 20 & SHOPIAN & 604 & 528 & 1132 & 548 & 407 & 955 & 56 & 121 & 177 \\
\hline 21 & SRINAGAR & 583 & 393 & 976 & 404 & 295 & 699 & 179 & 98 & 277 \\
\hline 22 & UDHAMPUR & 2343 & 1563 & 3906 & 2275 & 1453 & 3728 & 68 & 110 & 178 \\
\hline & Total & $\mathbf{5 3 3 2 3}$ & $\mathbf{4 1 5 9 4}$ & $\mathbf{9 4 9 1 7}$ & $\mathbf{5 0 3 7 4}$ & $\mathbf{3 8 5 8 1}$ & $\mathbf{8 8 9 5 5}$ & $\mathbf{2 9 4 9}$ & $\mathbf{3 0 1 3}$ & $\mathbf{5 9 6 2}$ \\
\hline
\end{tabular}

Source: SSA, Jammu

Though there is schooling facility available for all migratory populations during winter in the form of stationary and permanent government schools at different places all over the state but at the summer locations where the good numbers of nomadic children move with their parents, the educational facilities are less.

The challenges that the nomadic people face because of the violence in Jammu and Kashmir makes EFA appear illusionary. While rebuilding the education system proves challenging, security, stability, access to institutional resources and the absence of governmental support and finance remain the principal hurdles in developing and sustaining the delivery of education to the people of the region.

\section{Methodology}

The research is based on both primary as well as secondary sources. The researcher travelled to the twin border districts of Poonch and Rajouri and interviewed many Gujjar Bakkarwals nomadic tribes for the study. The participants responded to the study/questions about factors affecting access to universal primary education by nomadic pastoralists. The study employed questionnaires, interview schedules, Focused Group Discussions and document analysis as research instruments. The secondary sources including various government documents, reports, books, research papers in journals, J\&K economic surveys, magazines and periodicals have been consulted thoroughly for the present study.

\section{Research Objectives}

The study examined factors affecting access to Universal Elementary Education by the pastoralists in Jammu and Kashmir, especially the Gujjars and Bakkarwals in Poonch and Rajouri districts. The aims of the study were:

1. To understand issues that affect access to UEE among the nomadic children in Poonch and Rajouri District of J\&K.

2. To explore the extent to which pastoralists have been deprived of access to basic education while identifying major constraints that limit the provision of education to Gujjars and Bakkarwals.

3. To review attempts made by the $\mathrm{J} \& \mathrm{~K}$ government to provide education to nomads.

4. To identify problems related to the nomads' accessibility to education and to draw conclusions on pastoral nomads in relation to the provision of basic services.

5. To recommend suitable strategies through which education could be provided to nomads and which could ultimately help the J\&K government to enable them to supply this service in the best possible way.

\section{Mobile Schools for pastoralists}

\section{Results And Discussions}

Setting up mobile schools was an innovative idea introduced in the 1970s during the then J\&K chief minister Sheikh Abdullah's tenure. Mobile schools were usually seen as an 'alternative' system that can be assembled or disassembled within 30 minutes and carried conveniently by pack animals. Mobile schools that can be dismantled and quickly, where teachers with a minimum of materials move with the students have been tried in several countries with different degrees of success. Mobile schools and similar innovative projects have 
tended to be justified on the grounds of making education more accessible to pastoralists as a group, rather than in terms of a gendered analysis of accessibility.

The Jammu and Kashmir government, with the objective of upliftment of the community, not only set up a Gujjar Bakkarwal Advisory Board, but on the recommendations of the Board, many mobile schools were opened and Gujjar Bakkarwal Hostels were opened for the students at district levels. Normally, a teacher belonging to the Gujjar Bakkarwal communities who knew them well and would speak their language Gojri was taken as the mobile school teacher. He would travel along with the Gujjars Bakkarwals and teach their children. The aim behind setting up such schools was to provide elementary education up to class $\mathrm{V}$ with the help of teachers from their own community. However, the experiment could not continue for long as the armed conflict which erupted in 1990s witnessed the closure of many such schools while many of these were turned into stationary schools.

Mobile primary schools for the nomadic population in Jammu and Kashmir are generally a single teacher multi-grade school set up to provide schooling for small numbers of children travelling with their families in small groups schools. While any general primary school has three teachers, a mobile school has just one teacher. The mobile schools are quite different from other schools in the rural and urban areas. The group of Gujjar-Bakkarwal children in the age group of 4-11 study in such mobile schools.

Under the Mobile school system, makeshift classes are set up for the children between April and September. At the end of this period, the students can return to their 'home' schools or continue to study in the mobile schools which also move with the migratory populations to their winter locations.

As the armed conflict erupted in Jammu and Kashmir, a total of 175 mobile schools out of the total 263 were closed down and converted into regular schools. Out of these 88 schools are still mobile. However, the field research for the present study threw ample light over the fact that most of the schools which were still 'mobile', were only on paper and majority of those were not moving with the nomadic communities. Besides, all the mobile schools in Poonch district meant for the nomadic population have stopped moving with the migrating population while few schools in Rajouri still move with the nomads.

Because of the militancy in the State, the migratory schools were adversely hit. These could not function at the given points. Due to militancy, the mobile schools were made stationary schools as the teachers refused to go to the higher reaches in these mobile schools for the scare of the militants. With militancy creating terror in the far flung areas of Jammu, sometimes teachers would make the militancy as an excuse for not going to schools in these far flung areas, but at times the threat was real.

Most of these schools, because of security reasons, had to be shifted to safer places and the purpose for which these were set up was lost. Gujjars and Bakkarwals were at higher belts and the locations of these schools were at far-off places. The net result has been that educational advancement amongst the Gujjar and Bakkarwal community could not take deep roots. The hostels set up at district headquarters for Gujjars and Bakkarwals also did not come up to the expected levels. Schools lacked both manpower and infrastructural facilities.

\section{Challenges in the education of Gujjars and Bakkarwals in J\&K}

The literacy rate among the Gujjar and Bakkarwals is too low as compared to other inhabitants of the state. These tribal communities are already lagging behind the rest of the tribes and population of the trouble region.

Some of the challenges in the provision of educational services to transhumants areas are similar to those faced by other rural and marginalized households in the region, although often more severe. These include nomadism, militancy, lack of teachers willing to work in the conflict situations found in these areas, poor infrastructure as well as poorly motivated teachers, a household economy dependant on livestock, with children spending long periods away from their homes and schools and transhumant mobility.

In Jammu and Kashmir, Mobile Primary Schools have not been able to deliver on ground. Almost, all the schools are functioning in worst conditions and few steps have been taken to improve their functioning and providing teaching staff. There are hardly any facilities in these schools. No matting to sit on, no tents for protection from rain and sunshine, no blackboards and no uniforms. Children of these nomadic communities are unable to pursue education due to their lifestyle and low levels of income. Transhumance practice is the biggest impediment for those who want to ensure formal education for their children. Frequent seasonal migration is one of the biggest hurdles in the education of Gujjar and Bakkarwal community. During the migratory life most of them leave their education in primary level. Since they have mobile schools and they are up to 5th standard only, which keep moving with community members during the migration, after class $5^{\text {th }}$ there is no education facility which force the community members to left the education.

There is dearth of good teachers who can devote their time to educate these Gujjar and Bakkarwal children. Teachers hesitate to move with these nomadic Bakkarwals due to which most of them largely remain illiterate. 
There is no doubt that the mix of the government apathy and the effects of insurgent violence have led to the fall in the education standards over the last decade, affecting the educational prospects of Gujjar and Bakkarwal children.

\section{Conclusions And Suggestions}

This research shows that there is an increasing demand for access to education among the nomadic Gujjar and Bakkarwal communities in Jammu and Kashmir. Looking at the living condition of the nomads, it could be seen that much need to be done to improve the precarious situation if they are to get educated. Educational backwardness amongst Gujjars and Bakkarwals which is one of the key factors for their poverty, ignorance and overall backwardness should have been addressed on top priority basis from the very beginning, but this did not receive any serious attention.

There is a need to strengthen the mobile schools so that more and more nomadic children are able to take its advantage. As the violence in the state has waned to a large extent, the mobile schools which were made into stationary schools need to be converted back into mobile schools which can move with the nomadic population. Mobile schools are operating in some areas, but still on a small scale and largely outside the mainstream education system. Most of these are 'mobile' only on paper. As mobile schools provide a flexible model of education that is well-suited to the nomadic pastoralist lifestyle, these schools should immediately be directed to move with the nomadic population with no single school kept as stationary. In order to increase access to basic education and provide a sense of normalcy in the lives of nomadic children, structured activities must be provided in a safe and secure environment (Pigozzi, 1999, UNICEF, 2005). Mobile schools offer an atmosphere and mobile education offers favorable possibilities for achieving EFA. Thus the mobile schools which have been made stationary need to be strengthened and made mobile.

In 2011, the Jammu and Kashmir government had approved opening of 100 more mobile schools for the Gujjar and Bakkarwal communities of the state to enable the children of the migratory population receive proper education. However, even after a lapse of three years, nothing has been done in this regard. Enhancement in Mobile schools in each district of state and accountability of the teacher at various levels is important. The government should provide the students proper infrastructure and at least mid-day meal which is the right of these students. The state government should take some steps to promote and strengthen the mobile schools. The department should increase the number of mobile school at different places so that more children get benefited.

There is need to make the existing Gujjar and Bakkarwal mobile schools and hostels functional and result oriented. The existing Gujjar Boys Hostels should be turned into residential schools and also upgraded upto graduate level and Gujjar Girls Hostels can be established at district levels in both the Jammu and Kashmir provinces.

Keeping in view the educational backwardness, low rate of enrolment of Bakkarwals and Gujjars particularly the girl children in schools and the difficulties faced by first generation learners in non-Gojri medium of instruction, there is a need to link the child's home language with the school language /medium of instruction. There is need for adoption of mother tongue education up to primary level using bilingual / bidialectical approach in the schools to achieve the goal of universalisation of primary education among this community.

The Government needs to encourage private sector to invest in education in order to contribute effectively to access to education in nomadic communities. This may be achieved by providing incentive to private sectors with interest in investing in education in nomadic pastoralists' communities. The government has to move fast to address their problems at the earliest.

$\mathrm{J} \& \mathrm{~K}$ pastoralists are increasingly exposed to globalization and world economic trends. They are well aware that neither the mainstream education system through settled schools nor recent innovations such as mobile schools are working well. Transhumant and sedentary Gujjars and Bakkarwals see the relevance of formal education in various ways. Even though they live on the margins of literate society, Gujjars and Bakkarwals need a strong education system which has strong mobile schools besides stationary schools for nomadic population which can help the nomads adapt to these new challenges. While there is an important need to equip those who leave pastoralism to find employment in the wider economy, there is an equally urgent need for those children who are active pastoralists and will be responsible for tomorrow's animal production in the highlands, to have access to the same education as others. In both cases the aim must be to provide a level playing field for pastoralists in economic development. Lastly, the modern world is knocking on their door; nomads need to develop a sense of belonging to the larger, modern world wherein learning is a key commodity for survival.

\section{References}

[1]. Andrabi Azad Ahmad (2013), Development of Education of Scheduled Tribes in Jammu and Kashmir, International Journal of Social Science Tomorrow Vol. 2 No. 4 ISSN: 2277-6168

[2]. Bhardwaj, A.N. (1994), History and Culture of Himalayan Gujjars, J. K. Book House, Jammu 
[3]. Barro R, Lee JW (2001). "International Data on Educational Attainment: Updates and Implications," Oxford Economic Papers, 53(3): 541-563.

[4]. Census of India (2001 \& 2011), Jammu and Kashmir 2001, Registrar General of India, New Delhi

[5]. Dyer, C. \& Choksi, A. (1997), The demand for education among the Rabaris of Kutch, West India, Nomadic Peoples, 1 (2)

[6]. EFA Global Monitoring Report (2007) UNESCO, Paris

[7]. Elementary Education in India Analytical Report (2003), National University of Education Planning and Administration New Delhi

[8]. Fazili Ehsan (2007), Mobile schools boost literacy, The Tribune

[9]. GMR (2010), Reaching the marginalized. Education for All Global Monitoring Report 2010, Paris: UNESCO.

[10]. "Human Development Report (HDR) Paints Grim Picture of Literary Scenario, "Kashmir Observer, India 13 July 2008.

[11]. Kratli, S. (2000) Education Provision to Nomadic Pastoralists: a review of the literature (for the World Bank) (Sussex, IDS).

[12]. Krätli, S. and Dyer, C. (2009). Education For Nomads Issues Paper Educating Mobile Pastoralists: A strategic review of literature \#1.IIED: London.

[13]. Lucas Robert (1988). “On the Mechanics of Economic Development,” J. Monet. Econ. 22

[14]. Psacharopoulous G, Woodhall M (1985). Education for Development; An Analysis of Investment Choices. 108. Univers. J. Edu. Gen. Stud.Washington: World Bank.

[15]. Pigozzi, M. J. (1999). Education in Emergencies and for Reconstruction: A Developmental Approach. United Nations Children's Fund, Program Division Education, Document No. UNICEF/PD/ED/99-1

[16]. Rao, A.and Casimir, M. J. (1982). Mobile pastoralists of J\&K -- a preliminary report on tribal people, Journal of Nomadic People. 10:40-50

[17]. Sarva Shiksha Abhiyan, Annual Work Plan and Budget (AWP\&B) report of Jammu and Kashmir, 2011-2012

[18]. Sifuna DN (2005). Increasing Access and Participation of Pastoralists Communities in Primary Education in Kenya.Int. Rev. Edu. 51

[19]. UNESCO. (2000). Dakar Framework for Action: Education for All; Meeting our Collective Commitments. Paris: UNESCO Publishing

[20]. Warikoo, K. (2000). Tribal Gujjars of Jammu \& Kashmir. Himalayan and Central Asian Studies Vol. 4 No. 1 